\title{
PERANAN LINGKUNGAN KELUARGA (ORANG TUA) TERHADAP PERKEMBANGAN KEPRIBADIAN ANAK
}

\author{
Irawan hadi
}

\begin{abstract}
Family is the first environment recognized by children. Children spend most of their time with family. In family environment, parents have important roles in shaping children's personality because their habits can be imitated by the children. In a family, everyone is influential, but the father and mother are the most influential. Educating children is the most important task for parents because it can affect the success of the family. However, the success of the family means nothing if it fails in educating and shaping children's character and personality in accordance with the parents' expectations. Family is the most significant institution in shaping children's personalities. The essence of education is the responsibility of the family, while formal education is only a part of it. Parents have the greatest role to influence children when they are sensitive to external influences by educating them according to their own pace. Parents are the ones who should know best when and how their children learn.
\end{abstract}

\section{Keywords: Roles of Family on Child's Development}

\section{PENDAHULUAN}

Sejalan dengan perkembangan teknologi yang pesat semua lapisan masyarakat dihadapkan pada satu era yang disebut dengan era globalisasi. Dan orang menyadari bahwa dalam era globalisasi persaingan sangat ketat. Persaingan tersebut merupakan fenomena yang harus dihadapi oleh setiap orang. Tidak hanya bersaing dengan teman atau tetangga tetapi lebih dari itu, kita harus bersaing dengan orang dari negara lain. Dari uraian di atas paling tidak kita bisa menyimpulkan bahwa kemampuan seseorang untuk menguasai teknologi canggih yang diimbangi dengan suatu kepribadian yang tangguh dan siap untuk bersaing merupakan persyaratan pokok bagi seseorang untuk bisa tetap eksis di antara orang-orang disekitarnya. 
Keluarga, yang menghadirkan anak kedunia ini, secara kodrat bertugas mendidik anak itu, sejak kecil si anak hidup tumbuh dan berkembang di dalam keluarga itu. Seluruh isi keluarga itu yang mula-mula mengisi pribadi anak-anak, orang tua dengan secara tidak direncanakan menanamkan kebiasaan-kebiasaan yang diwarisi dari nenek moyang dan pengaruh-pengaruh lain yang diterimanya dari masyarakat. Pengaruh itu tidak akan dapat hilang begitu saja sekalipun pada waktu besarnya si anak telah meninggalkan lingkungan itu dan hidup di lingkungan yang lain ${ }^{1}$. Dan disatu pihak si anak memperlihatkan faktor-faktor individualitasnya dalam menghadapi rangsangan-rangsangan ini tetapi dipihak lain ia mulai menanamkan pola-pola khusus akibat rangsangan tersebut. Pola-pola inilah yang kemudian menjadi pola-pola dasar perkembangan kepribadian. Penyelidikan para ahli menyimpulakan bahwa sekalipun si bayi belum dapat didik, dalam arti belum dapat menangkap pengertian-pengertian, akan tetapi si bayi seolah-olah menyadari perlakuan-perlakuan mana yang "Penuh Kasih" dan perlakuan mana yang tidak disertai "kasih sayang". 2

\section{PEMBAHASAN}

\section{Pengertian Keluarga}

Menurut Lubis Keluarga adalah

Kesatuan terkecil dalam masyarakat yang terdiri dari ayah, ibu, dan anak. Ada tiga bentuk kelurga yaitu Nuclear Family (terdiri dari ayah, ibu, dan anak), Extended Family (terdiri dari ayah, ibu, anak, nenek, kakek, paman, atau bibi), dan Blended Family (keluarga inti ditambah dengan anak dari pernikahan suami/isteri sebelumnya).klien adalah bagian dari salah satu bentuk dari keluarga tersebut. ${ }^{9}$

Keluarga pada hakekatnya merupakan satuan terkecil sebagai inti dari suatu sistem sosial yang ada dimasyarakat. Sebagai satuan terkecil, keluarga

\footnotetext{
${ }^{1}$ Agung Sujana, Halem Lubis dan Taufik Hadi. Psikologi Kepribadian (ed-I. Cet. IX ; Jakarta : Bumi Aksara 2001) h. 8

${ }^{2}$ Singgih Gunarsa, Psikologi Perkembangan. (Cet. II; Jakarta : Gunung Mulia, 1995), 910.

${ }^{9}$ Namora Lumongga Lubis, Memahami Dasar-Dasar Konseling (Jakarta: Prenada Media Group, 2011), 220.
} 
merupakan miniatur dan embrio berbagai unsur sistem sosial manusia. Suasana yang kondusif akan menghasilkan warga masyarakat yang baik karena didalam keluargalah seluruh anggota keluarga belajar berbagai dasar kehidupan bermasyarakat. ${ }^{10}$

Di sisi lain Departemen Kesehatan Republik Indonesia merumuskan tentang pengertian keluarga, yaitu satuan unit terkecil dari masyarakat yang terdiri atas kepala keluarga dan beberapa orang yang berkumpul dan tinggal di suatu tempat di bawah suatu atap dalam keadaan saling ketergantungan. ${ }^{11}$

Keluarga merupakan satuan persekutuan hidup yang paling mendasar dan merupakan pangkal kehidupan bermasyarakat.di dalam keluargalah setiap warga masyarakat menilai kehidupannya dan dari keluargalah setiap individu dipersiapkan untuk menjadi masyarakat. Palmo, Lowry, Weldon dan Scioscia mengidentifikasikan perubahan perubahan yang terjadi secara signifikan mempengaruhi struktur dan kondisi keluarga, yaitu meningkatnya perceraian, kedua orang tua bekerja, pengangkatan anak, emansipasi pria dan wanita, kebebasan hubungan seksual.

Selain itu meningkatnya kesadaran tantang anak-anak cacat, keadaan depresi dan bunuh diri, kesulitan mencari pekerjaan dan ketidak mampuan ekonomi pada umumnya menambah unsur-unsur yang mempengaruhi kehidupan keluarga. Unsur-unsur yang tidak menguntungkan itu secara langsung maupun tidak langsung membawa pengaruh kepada anggota keluarga, baik pendidikan di sekolah maupun yang tidak bersekolah lagi. mereka yang sudah dewasa maupun yang masih muda, baik mereka yang masih mengikuti permasalahan yang ditimbulkan oleh pengaruh yang tidak menguntungkan itu mengundang peranannya bimbingan dan konseling kedalam keluarga. ${ }^{12}$

Konseling keluarga sebagai suatu proses interaktif yang berupaya membantu keluarga memperoleh keseimbangan homeostatis (kemampuan

\footnotetext{
${ }^{10}$ Novi Hendri, Psikologi Dan Konseling Keluarga (Medan: Citapustaka media perintis, 2012), 11.

${ }^{11}$ Arifuddin, Keluarga Dalam Pembentukan Akhlak Islamiah (Yogyakarta: Ombak, 2009), 52.

${ }^{12}$ Abu bakar M.luddin, Dasar-Dasar Konseling (Bandung: Cita Pustaka Media Perintis, 2009), 149 .
} 
mempertahankan keluarga dalam keadaan seimbang) sehingga anggota keluarga dapat merasa nyaman. Konseling keluarga merupakan proses bantuan kepada individu dengan melibatkan para anggota keluarga lainnya dalam upaya memecahkan masalah yang dialami.

\section{Tujuan Keluarga}

Adapun tujuan dari konseling keluarga pada hakikatnya merupakan layanan yang bersifat profesional yang bertujuan untuk mencapai tujuan-tujuan sebagai berikut:

1. Membantu anggota keluarga belajar dan memahami bahwa dinamika keluarga merupakan hasil pengaruh hubungan antar anggota keluarga.

2. Membantu anggota keluarga dapat menerima kenyataan bahwa bila salah satu anggota keluarga mengalami masalah, dia akan dapat memberikan pengaruh, baik pada persepsi, harapan, maupun interaksi dengan anggota keluarga yang lain.

3. Upaya melaksanakan konseling keluarga kepada anggota keluarga dapat mengupayakan tumbuh dan berkembang suatu keseimbangan dalam kehidupan berumah tangga.

4. Mengembangkan rasa penghargaan diri dari seluruh anggota keluarga kepada anggota keluarga yang lain.

5. Membantu anggota keluarga mencapai kesehatan fisik agar fungsi keluarga menjadi maksimal.

6. Membantu individu keluarga yang dalam keadaan sadar tentang kondisi dirinya yang bermasalah, untuk mencapai pemahaman yang lebih baik tentang dirinya sendiri dan nasibnya sehubungan dengan kehidupan keluarganya. ${ }^{13}$

\section{Peran Keluarga}

Peran keluarga menggambarkan seperangkat perilaku interpersonal yang berhubungan dengan posisi dan situasi tertentu. Berbagai peran yang terdapat dalam keluarga adalah sebagai berikut:

1. Peran Ayah sebagai pencari nafkah, pendidik, pelindung dan pemberi rasa aman, kepala rumah tangga, anggota dari kelompok sosialnya dan anggota Masyarakat.

2. Peran ibu sebagai isteri, ibu dari anaknya, mengurus rumah tangga, pengasuh, pendidik dan pelindung bagi anak-anaknya, anggota

\footnotetext{
${ }^{13}$ Ibid, 26.
} 
kelompok social dan anggota masyarakat serta berperan sebagai pencari nafkah tambahan bagi keluarga.

3. Peran anak-anak sebagai pelaksana peran psikososial sesuai dengan tingkat perkembangan baik fisik, mental dan spiritual. ${ }^{14}$

\section{Fungsi Keluarga}

Fungsi dari keluarga adalah memenuhi kebutuhan anggota individu keluarga dan masyarakat yang lebih luas. Adapun fungsinya yaitu sebagai berikut:

1. Fungsi sosialisasi yaitu proses perkembangan dan perubahan yang dilalui individu yang menghasilkan interaksi sosial dan belajar berperan dalam lingkungan sosial. Proses sosialisasi dimulai sejak lahir. Keluarga merupakan tempat individu untuk belajar sosialisasi. Anggota keluarga belajar disiplin, belajar tentang norma-norma, budaya dan perilaku melalui hubungan dan interaksi dalam keluarga.

2. Fungsi Reproduksi yaitu keluarga mempunyai fungsi produksi, karena keluarga dapat menghasilkan keturunan secara sah.

3. Fungsi Ekonomi yaitu kesatuan ekonomi mandiri, anggota keluarga mendapatkan dan membelanjakan harta untuk memenuhi keperluan

4. Fungsi Protektif yaitu keluarga harus senantiasa melindungi anggotanya dari ancaman fisik, ekonomis dan psiko sosial. Masalah salah satu anggota merupakan masalah bersama seluruh anggota keluarga.

5. Fungsi Rekreatif yaitu keluarga merupakan pusat rekreasi bagi para anggotanya. Kejenuhan dapat dihilangkan ketika sedang berkumpul atau bergurau dengan anggota keluarganya.

6. tolong menolong diantara anggota keluarganya, baik antara orang tua terhadap anak-anaknya maupun sebaliknya.

7. Fungsi Edukatif yaitu keluarga memberikan pendidikan kepada anggotanya, terutama kepada anak-anak agar anak-anak tumbuh menjadi anak yang mempunyai budi pekerti luhur. Sehingga keluarga merupakan tempat pendidikan yang paling utama. ${ }^{15}$

Hal ini sesuai dengan firman Allah Swt (QS. Ar-Ruum [30]: 21)

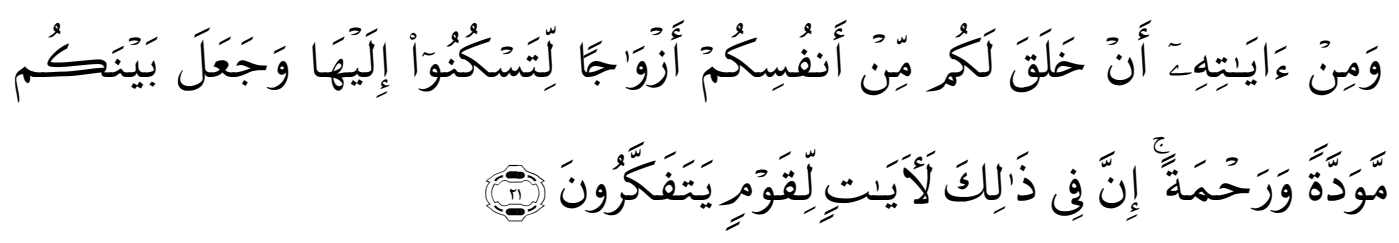

${ }^{14}$ Arifuddin, Keluarga, 53.

${ }^{15}$ Ibid, 
Terjemahnya:

"Dan di antara tanda-tanda kekuasaan-Nya ialah Dia menciptakan untukmu isteri-isteri dari jenismu sendiri, supaya kamu cenderung dan merasa tenteram kepadanya, dan dijadikan-Nya di antaramu rasa kasih dan sayang. Sesungguhnya pada yang demikian itu benar-benar terdapat tanda-tanda bagi kaum yang berfikir."16

Menurut Katsir adalah seandainya allah menciptakan anak Adam seluruhnya laki-laki dan menjadikan wanita dari jenis yang lainnya, seperti dari bangsa jin atau hewan, niscaya perasaan kasih sayang di antara mereka dan di antara berbagai pasangan tidak akan tercapai, bahkan akan terjadi ketidak senangan seandainya pasangan-pasangan itu berbeda jenis.

Kemudian di antara rahmat-Nya kepada manusia adalah menjadikan pasangan-pasangan mereka dari jenis mereka sendiri serta menjadikan perasaan cinta dan kasih sayang di antara mereka. Dimana adakalanya seorang laki-laki mengikat wanita dikarenakan rasa cinta atau rasa kasih sayang dengan lahirnya seorang anak, seling membutuhkan nafkah dan kasih sayang di antara keduanya. ${ }^{17}$ Dalam kedua contoh diatas, kita menjumpai suatu konsep baru, yaitu “perasaan", yang disamping segala macam pengetahuan agaknya juga mengisi alam kesadaran manusia setiap saat dalam hidupnya. Apabila kita perhatikan kedua contoh diatas dengan seksama, "perasaan" adalah suatu keadaan dalam kesadaran manusia yang karena pengetahuannya dinilai sebagai keadaan yang positif atau negatif. Suatu perasaan yang selalu bersifat sunbyektif karena adanya unsur penilaian tadi, biasanya menimbulkan "kehendak" dalam kesadaran individu. Kehendak itu mungkin positif yaitu individu yang bersangkutan ingin mendapatkan hal yang dirasakannya memberi kenikmatan atau mungkin juga negatif yaitu individu yang bersangkutan ingin menghindari hal yang dirasakannya membawa perasaannya tidak nikmat.

\footnotetext{
${ }^{16}$ Departemen Agama RI, Alqur'an dan Terjemahnya (Bandung, Mizan, 2009), 407.

${ }^{17}$ Ibnu Katsir, Tafsir Ibnu Katsir (Jilid 7) Cetakan Ke. II (Jakarta: Pustaka Imam AsSyafi'I, 2010), 168.
} 


\section{Pengertian Kepribadian}

Defenisi mengenai kepribadian itu tidak hanya berbeda dengan arti yang melekat pada konsep itu dalam bahasa sehari-hari. Dalam bahasa populer istilah "kepribadian" juga berarti ciri ciri watak yang konsisten, sehingga seorang individu memiliki suatu identitas yang khas. Kalau dalam bahasa sehari hari kita mengatakan bahwa seseorang memiliki kepribadian, yang dimaksudkan ialah bahwa individu tersebut memilik beberapa ciri watak yang diperlihatkan secara konsisten dan konsekuen, yang menyebabkan bahwa ia memiliki identitas yang berbeda dari individu individu lainnya. Konsep kepribadian yang lebih tajam tetapi seragam agakanya belum ada karena konsep tersebut sangat luas dan merupakan suatu kontruksi yang sukar dirumuskan dalam satu definisi yang tajam tetapi mencangkup seluruhnya. Oleh karena itu, bagi kita yang belajar antropolgi, kirany cukup apabila untuk sementara kita gunakan saja defenisi yang masih "kasar" tersebut diatas, dan penggunaan defenisi definisi yang lebih tajam untuk keperluan analisa yang lebih mendalam sebaiknya kita serahkan kepada para ahli pisikologi saja.

\section{Unsur-Unsur Kepribadian}

\section{Pengetahuan}

Unsur-unsur yang mengisi akal dan alama jiwa orang yang sadar, terkandung didalam otaknya secara sadar. Dalam alam sekitar manusia terdapat berbagi hal yang diterimanya melalui panca indranya serta melalui alat penerima yang lain, misalnya getaran eter (cahaya dan warna), getaran akustik (suara), bau, rasa, sentuhan, tekanan mekanikal (berat/ringan), tekanan termikal (panas/dingin), dan lain lain, yang masuk kedalam berbagai sel di bagian bagian tertentu dari otaknya. Disana berbagai macam proses fisik, fisiologi, dan pisikologi terjadi, sehingga getaran getaran dan tekanan tekanan tadi diolah menjadi satu susunan yang dipancarkan atau di proyeksikan oleh individu yang 
bersangkutan menjadi suatu gambaran tentang lingkungan sekitarnya. Dalam ilmu Antropologi, seluruh proses akar manusia yang sadar itu tersebut "persepsi". ${ }^{18}$

Ada kalanya suatu presepsi yang diproyeksikan kembali menjadi suatu pengambaran berfokus tentang lingkungan yang mengandung bagian bagian yang menyebabkan bahwa ia tertarik kepada bagian bagian tertentu, individu itu akan memusatkan akalnya secara lebih intensif terhadap bagian bagian yang khusus. Pengambaran yang terfokus secara lebih intensif yang terjadi karena pemusatan secara lebih intensif itu, dalam pisikologi itu disebut "pengamatan".

Cara pengamatan seperti itu menyebabkan bahwa pengambaran tentang lingkungan mungkin ada yang ditambah tambah atau dibesar besarkan, tetapi ada pula yang dikurangi atau diperkecil pada bagian bagian tertentu. Ada pula yang digabung gabungkan dengan pengambaran pengambaran lain sehingga menjadi pengambaran yang baru sama sekali, yang secara nyata sebenarnya tidak akan pernah ada. Pengambaran baru yang sering ali tidak realistik itu dalam pisikologi disebut "fantasi".

Seorang dapat juga mengabungkan dan membandingkan-bandingkan bagian-bagian dari suatu penggambaran dengan bagian-bagian dari berbagai penggambaran lain yang sejenis secara konsisten berdasarkan asas asas tertentu. Dengan proses akal itu ia memiliki kemampuan untuk membentuk suatu penggambaran baru yang abstrak, yang dalam kenyataannya tidak mirip dengan salah satu dari sekian macam bahan kongkret dari penggambaran yang baru. Dengan demikian manusia dapat membuat suatu penggambaran tentang tempattempat tertentu di muka bumi bahkan juga diluar bumi, padahal ia belum pernah melihat, atau mempresepsikan tempat-tempat tadi. Penggambaran abstrak tadi dalam ilmu sosisal disebut "konsep".

Seluruh penggambaran, apersepsi, pengamatan, konsep, dan fantasi merupakan unsur unsur pengetahuan yang secara sadar dimiliki seorang individu. Sebaliknya banyak pengetahuan atau bagian bagian dari seluruh pengetahuan yang berhasil dihimpun seseorang selama hayatnya, dapat hilang dari akalnya

\footnotetext{
${ }^{18} \mathrm{https}: / /$ www.academia.edu > MAKALAH_KEPRIBADian, Diakses 27 November 2021.
} 
yang sadar yang disebabkan oleh berbagai sebab, yang banyak dipelajar ilmu pisikologi. Walaupun demikian perlu diperhatikan bahwa unsur-unsur pengetahuan sebenarnya tidak hilang atau lenyap begitu saja akan tetapi hanya terdesak ke bagian jiwanya yang dalam ilmu pisikologinya disebut "alam bawah sadar". 19

Dalam alam bawah sadar itu, berbagai pengetahuan larut dan terpecah pecah menjadi bagian bagian yang tidak teratur. Proses itu terjadi karena akal sadar individu yang bersangkutan tidak lagi menyusun dan menatanya dengan rapi, walaupun bagian bagian tertentu dari pengetahuan tadi ada kalanya muncul ke alam sadarnya.setiap orang tentu pernah tiba tiba teringat akan suatu hal baik dalam keadaan utuh atau sepotong potong atau bahkan tercampur campur dengan berbagai pengetahuan atau pengalaman lain yang telah dilupakannya.

Pengetahuan seseorang karena berbagai sebab juga dapat terdesak atau dengan sengaja dibuat terdesak oleh individu yang bersangkutkan, kedalam bagian dari jiwanya yang lebih dalam, yaitu bagian yang dalam ilmu pisikologi disebut "alam tak sadar". Dalam alam tak sadar itu pengetahuan larut dan terpecah pecah kedalam bagian bagian yang tercampur aduk. Bagian bagian dari pengetahuan yang tercampur aduk itu ada kalanya muncul kembali terutama pada saat saat akal yang mengatur alam kesadaran berada dalam keadaan relaks atau tak berfungsi.

Proses proses pisikologi yang terjadi dalam alam bahwa sadar dan tak sadar, yang banyak dipelajari oleh bagian dari pisikologi yang dikembangkan oleh S. Freud, yaitu ilmu pisikoanalisa, tidak akan kita perhatikan lebih lanjut dalam buku ini untuk mendapatkan pengertian mengenai asas asas kehidupan masyarakat dan kebeudayaan manusia, untuk sementara kita hanya akan memperhatian bagian kesadaran dari alam jiwa manusia saja.

${ }^{19} \mathrm{https} / / / \mathrm{www}$. academia.edu > MAKALAH_KEPRIBADian, Diakses 27 November 2021. 


\section{Perasaan}

Selain pengetahuan, alam kesadaran manusia juga mengandung berbagi macam "perasaan". skalau pada suatu hari yang luar biasa panasnya kita melihat papan iklan bergambar minuman coca cola yang tampak sejuk dan nikmat, maka presepsi itu menyebabkan bahwa kita membayangkan gelas coca cola yang dingin dan pengambaran itu dihubungkan oleh akal kita dengan penggambaran lain yang muncul kembali sebagai kenangan dalam kesadaran kita, menjadi suatu apresepsi tentang diri sendiri yang sedang menikmati coca cola dingin, manis, dan menyegarakan pada saat hari sangat panas, yang menyebabkan air liur keluar dengan sendirinya.apresepsi orang yang menggambaran dirinya sendiri tengah menikmati coca cola dingin itu menimbulkan suatu "perasaan" yang positif dalam kesadarannya yaitu perasaan nikmat, sampai sampai air liurnya itu benar benar keluar. $^{20}$

Sebaliknya, kita dapat juga menggambarkan individu yang melihat suatu hal yang buruk atau mendengar suara yang tidak menyenangkan, mencium bau busuk, dan sebgainya. Presepsi presepsi seperti itu dapat menimbukan kesadarannya perasaan negatif, karena ia terkenang bagaimana ia menjadi muak setelah mencium ikan yang busuk dimasa lampau. Apresepsi itu mungkin dapat menyebabkan menjadi benar benar muak pada waktu ia mencium ikan busuk lagi.

Dalam kedua contoh diatas, kita menjumpai suatu konsep baru, yaitu “perasaan”, yang disamping segala macam pengetahuan agaknya juga mengisi alam kesadaran manusia setiap saat dalam hidupnya. Apabila kita perhatikan kedua contoh diatas dengan seksama, "perasaan" adalah suatu keadaan dalam kesadaran manusia yang karena pengetahuannya dinilai sebagai keadaan yang positif atau negatif. Suatu perasaan yang selalu bersifat sunbyektif karena adanya unsur penilaian tadi, biasanya menimbulkan "kehendak" dalam kesadaran individu. Kehendak itu mungkin positif yaitu individu yang bersangkutan ingin mendapatkan hal yang dirasakannya memberi kenikmatan atau mungkin juga

${ }^{20}$ https://www.academia.edu > MAKALAH_KEPRIBADian, Diakses 27 November 2021. 
negatif yaitu individu yang bersangkutan ingin menghindari hal yang dirasakannya membawa perasaannya tidak nikmat.

\section{Dorongan Naluri}

Kesadaran manusia menurut para ahli pisikologi juga mengandung berbagai perasaan lain yang tidak ditimbukan karena dipengaruhi oleh pengetahuannya, tetapi karena memang sudah terkandung didalam organismenya, khusunya dlam gennya sebagai naluri. Kemauan yang sudah merupakan naluri disebut "dorongan". Walaupun diantara para ahli pisikologi ada perbedaan paham mengenai jenis dan jumlah dorongan naluri yang terkandung dalam naluri manusia, mereka semua sependapat bahwa ada sendikitnya 7 macam dorongan naluri :

a. Dorongan untuk mempertahankan hidup, dorongan ini memang merupakan suatu kekuatan biologis yanga ada pada setiap makhluk di dunia untuk dapat bertahan hidup.

b. Dorongan sex, dorongan ini telah banyak menari perhatian para ahli antropologi, dan mengenai hal ini telah dikembangkan berbagai teori. Dorongan biologis yang mendorong manusia untuk membentuk keturunan bagi kelanjutan keberadaanya didunia ini muncul pada setiap individu yang normal yang tidak dipengaruhi oleh pengetahuan apapun.

c. Dorongan untuk berupaya mencari makan, Dorongan inin tidak perlu dipelajari, dan sejak baru dilahirkanpun manusia telah menampakkannya dengan mencari puting susu ibunya atau botol susunya tak perlu diajari.

d. Dorongan untuk bergaul atau berinteraksi dengan sesama manusia, yang memang merupakan landasan biologi dari kehidupan masyarakat manusia sebagai makhluk kolektif

e. Dorongan untuk meniru tingkah laku sesamanya, Dorongan ini merupakan asal mua dari adanya beragam kebudayaan manuia, yang menyebabkan bahwa manuia mengembangkan adat. Adat sebaliknya memaksa perbuatan yang seragam dengan manusia-manuia disekelilingnya. 
f. Sorongan untuk berbakti, Dorongan ini mungkin ada karena manusia adalah makhluk kolektif . agar manusia dapat hidup serasi bersama manusia lain diperlukan suatu landasan biologi untuk mengembangkan altruisme, simpati, cinta, dan sebagainya

g. Dorongan untuk keindahan yang berbentuk warna, suara, dan gerak, Dorongan ini sering kali sudah tampak dimiliki bayi, yang sudah dimulai tertarik pada betuk-bentuk, warna-warna, dan suara-suara, irama, dan gerak-gerk. Ini berdasarkandari unsur kesenian. ${ }^{21}$

\section{METODE}

Metode penelitian kualitatif adalah metode yang akan dipakai dalam penelitian ini. Penelitian kualitatif adalah penelitian yang bersifat deskriptif dan cenderung menggunakan analisis. Landasan teori dimanfaatkan sebagai pemandu agar fokus penelitian sesuai dengan fakta di lapangan. Selain itu landasan teori ini juga bermanfaat untuk memberikan gambaran umum tentang latar penelitian dan sebagai bahan pembahasan hasil penelitian. Jenis pendekatan penelitian yang digunakan yaitu metode deskriptif, yaitu suatu metode dalam meneliti status sekelompok manusia, suatu objek, suatu set kondisi, suatu sistem pemikiran ataupun suatu kelas peristiwa pada masa sekarang. Tujuan dari penelitian deskriptif ini adalah untuk membuat deskripsi, gambaran, atau lukisan secara sistematis, faktual dan akurat mengenai fakta-fakta, sifatsifat serta hubungan antarfenomena yang diselidiki.

Jenis metode deskriptif yang dilakukan yaitu penelitian perpustakaan Penelitian perpustakaan merupakan kegiatan mengamati berbagai literatur yagn berhubungan dengan pokok permasalahan yang diangkat baik itu berupa buku, makalah ataupun tulisan yang sifatnya membantu sehingga dapat dijadikan sebagai pedoman dalam proses penelitian. Menurut Kartono dalam Sari et. al, dalam buku Pengantar Metodologi Research Sosial mengemukakan bahwa tujuan penelitian perpustakaan adalah untuk 
mengumpulkan data dan informasi dengan bantuan bermacam-macam material yang ada di perpustakaan, hasilnya dijadikan fungsi dasar dan alat utama bagi praktek penelitian di lapangan. Karena menggunakan penelitian perpustakaan berarti sumber data diambil dari berbagai sumber data yang relevan dengan topic yang diangkat yaitu peranan lingkungan keluarga (orang tua) terhadap perkembangan kepribadian anak. ${ }^{22}$

\section{PEMBAHASAN}

\section{Peran Orang Tua}

Keluarga merupakan lembaga sosial bagi umat untuk memenuhi kebutuhan yang diperlukan untuk kelangsungan hidupnya. Termasuk didalamnya kebutuhan pisiologis dan kebutuhan psikologis.

\section{Kebutuhan psikologis organis dan kebutuhan psikis}

\section{a. Kebutuhan psikologi-organis}

Termasuk dalam kebutuhan golongan ini ialah makanan, air dan oksigen. Kebutuhan ini sangat vital untuk melangsungkan hidupnya. Artinya, bila kebutuhan-kebutuhan tidak terpenuhi akan menyebabkan individu ini tidak dapat melangsungkan hidupya. Karena itu, kebutuhan ini disebut kebutuhan primer. Dan ini tidak berarti bila sesuatu kebutuhan tidsak atau belum terpenuhi lantas menyebabkan kematian, karena individu itu dalam batas tertentu masih dapat memenuhi kebutuhannya melalui "cadangan-cadangan" yang terdapat dalam dirinya. Kebutuhan psikologis organis menyebabkan timbulnya semacam tenaga atau kekuatan dalam bentuk dorongan yang menuntut untuk bertingkah laku. ${ }^{3}$

\section{b. Kebutuhan Psikis}

Bila hal-hal yang tersebut diatas bersangkut paut dengan obyek yang konkrit maka kebutuhan yang termasuk golongan ini merupakamn kebutuhan akan suatu yang tidsak terwujud. Sekalipun kebutuhan ini sering diklasipiksikan

\footnotetext{
${ }^{22}$ Widya Sari, Andi Muhammad Rifki, dan Mila Karmila, Analisis Kebijakan Pendidikan Terkait Implementasi Pembelajaran Jarak Jauh Pada Masadarurat Covid19, Karmila, https://jurnal.iain-bone. Ac id/in dex.p hp/mappe sona/articl e/download /830/562. ${ }^{3}$ Munarsa, Psikologi, 17.
} 
306 | MUSA WA, Vol. 13 No.2 Desember 2021 : 293-319

sebagai kebutuhan sekunder, hal ini bukan berarti kurang penting bila dibandingkan dengan yang pertama, seolah-olah tingkatan yang penting bahkan ditinjau dari dari sudut kesejahteraan, maka kebutuhan golongan kedua ini merupakan faktor yang ikut menentukan tercapainya taraf kesejahteraan yang baik, yang sehat madani, roh maupun sosial. Beberapa contoh kebutuhan psikis ialah:

1) Kebutuhan akan kasih sayang

2) Kebutuhan akan rasa aman, terlindung jauh dari perasaan takut, cemas.

3) Kebutuhan akan kebebasan menyatakan diri

4) Kebutuhan mengadakan hubungan dengan sesama teman, pergaulan.

5) Kebutuhan akan rasa harga diri. ${ }^{4}$

\section{c. Mengembangkan kreativitas anak}

Kreativitas adalah kombinasi baru dari elemen-elemen yang sudah ada. ${ }^{5}$ Macam-macam dalam mengembangkan kreativitas anak sebagai berikut:

1) Mestimulasi perkembangan otak anak

Misalnya : Memberi gizi yang cukup, mendengar musik klasik ketika masih dalam kandungan, membacakan dongeng-dongeng yang mengandung nilainilai luhur ketika masih dalam kandungan sampai kanak-kanak.

2) Kreativitas memang diturunkan tetapi lingkungan yang mendukung juga penting untuk hasil optimal.

Bronfenbrener dan Ciggal berpendapat bahwa faktor keturunan tidak langsung menghasilkan sifat akhir, tetapi berinteraksi dengan pengalaman yang diperoleh dari lingkungan. Artinya, orang tidak hanya punya bakat yang diturunkan, tetapi ia juga harus mendapatkan pengalaman yang membentuk bakatnya menjadi semakin sempurna.

${ }^{4}$ Ibid, 19

${ }^{5}$ Sri Widayati, Dkk, Reformasi Penbdidikan Dasar (Jakarta: PT. Grasindo; 2002), 45. 
3) Kreativitas berkaitan dengan traet/sifat-sifat atau kepribadian.

Sifat dan kepribadian adalah gabungan bawaan dan bentukan lingkungan Sifat-sifat berkaitan dengan kreativitas adalah:
a) Instrumental
b) Prestatif
c) Keluwesan bergaul
d) Kerja keras
e) Keyakinan diri
f) Pengambilan resiko
g) Swa kendali
h) Inovatif
i) Kemandirian

\section{Kreativitas berkaitan dengan kapasitas kreativitas intelegensi}

Woodworth dalam Mangkunegara berpendapat bahwa intelegensi adalah suatu tindakan yang bijaksana dalam menghadapi setiap situasi secara cepat dan tepat. ${ }^{6}$

Ingatlah bahwa ada 8 jenis intelegensi dan kenalilah anak anda, ia menonjol dibidang apa. Setelah itu berikanlah pendidikan yang terbaik sesuai dengan bakat dan minatnya. Untuk itu perlu bantuan dari orang tua dan mengisi waktu luang anak, sehingga dapat bermanfaat dengan optimal.

\section{Kreativitas berkaitan dengan faktor kognitif}

Para peneliti telah mengidentifikasi sejumlah kemampuan kognitif yang berkaitan dengan kreativitas. Caroll dalam Mangkunegara menemukan 8 faktor utama yang mempengaruhi faktor sekunder produksi gagasan, yakni:
a.Lancar / fasih membuat asosasi
b.Lancar berkreasi
c.Lancar berfikir atau menimbang
d.Lancar ide-ide
e.Lancar bicara
f. Lancar kata-kata
g.Lancar gagasan-gagasan praktis
h.Lancar keaslian ${ }^{23}$

${ }^{6}$ Anwar Prabu Mangkunegara. Perkembangan Intelegensi Anak dan Pengukuran IQ-nya (Cet. 10, Bandung : Angkasa 1993), 9.

${ }^{23}$ Ibid., 


\section{Kreativitas berkaitan dengan motivasi}

Untuk mampu memiliki sifat seperti ini, anak sejak dini harus dilatih untuk bertanggung jawab. Orang tua perlu memberikan dorongan supaya anak mau terus berusaha menguasai pengetahuan dan keterampilan. Proses belajar harus mendorong munculnya kreativitas

1) Belajar konstruktivisme. Anak dilatih membangun suatu konsep pengetahuan yang menyeluruh.

2) Belajar menemukan. Anak dilatih sendiri menemukan jawaban persoalanpersoalan yang harus diselesaikan, disesuaikann dengan masa pertumbuhannya.

3) Belajar dan bereksplorasi. Anak diberi kesempatan untuk melihat berbagai keindahan dunia dan dibantu menemukan keunikan-keunikan yang ada dibaliknya.

4) Tugas-tugas realistis dan berarti (belajar berdasarkan obyek) misalnya, ketika belajar matematika, persoalan yang dikemukakan dikaitkan dengan realitas hidup sehari-hari. Memberikan masukan (umpan balik) secara benar. Ketika anak melakukan suatu yang benar, baik, menakjubkan, maka ia perlu diberi pujian, jika perlu diberikan hadiah.

\section{Memahami sifat-sifat khas anak.}

Anak-anak memiliki dunianya sendiri. hal itu, ditandai dengan banyaknya gerak, penuh semangat, suka bermain pada setiap tempat dan waktu, tidak mudah letih dan cepat bosan. Ia merasa tidak mampu dan menyenangi tindakan-tindakan yang tidak tepat dan tidak tenang. Tetapi menyukai keadaan alamiah yang merupakan ungkapan dari kebutuhan kejiwaan yang terdalam guna memahami kejadian-kejadian disekitarnya.

Anak-anak biasanya melepaskan sifat hidup pada benda-benda yang mati dan membayangkan bahwa benda-benda itu adalah materi hidup yang punya perasaan, punya rasa, punya emosi, ia juga berkeyakinan bahwa benda-benda itu bisa menanggapinya. Dari segi emosi anak-anak bersifat resposif, peka, kuat, dan berubah-ubah. Karena itulah pendidikan pada anak hendaknya berusaha mantransfer emosi, perhatian, dan perasaan dalam diri pendidik kepada diri anak melalui metode komunikasi perasaan dan hati. 
Kita harus membedakan setiap individu di antara anak-anak karena mereka bukan buku yang kelak sama, juga tidak sejajar sebagaimana gigi-gigi sisir. Anakanak tersebut berbeda kemampuannya antara satu dengan yang lain. ${ }^{7}$

a. Mengatasi masalah pada anak.

Setiap keluarga mengalami dan harus memecahkan persoalannya sendirisendiri. apabila kesadarannya tidak disadari, tidak dirasakan sebagai persoalan, maka tentu tidak akan dicari cara-cara untuk mengatasinya.

b. Permasalahan anak dalam hubungan dengan sekolah

1) Kekurangan dalam hal fisik anak panca indera

2) Kekurangan pada indera penglihatan

3) Pada umumnya anak yang kekurangan daya pikiran daya penglihatan diharuskan memakai kecamata.

4) Kurangan pada indera pendengaran dapat mengganggu penerimaan pelajaran di sekolah, maka anak diberikan alat Bantu pendengaran.

5) Kesulitan-kesulitan oleh kurang "campur tangan" orang tua atau siapa saja dalam tata cara hidup dan perencanaan waktu anak.

6) Anak yang telah mendapatkan pekerjaan rumah secara teratur, perlu dibuatkan jadwal belajar dirumah. Jadwal belajar yang meliputi, masa belajar, istirahat dsan bermain harus disesuaikan dengan umur anak. Makin bertambah umur anak makin lama waktu belajar. ${ }^{8}$

\section{Teknik pemecahan masalah antara anak dan orang tua.}

a. Mencegah kebiasaan anak berbohong

Berbohong atau pendusta merupakan perbuatan pemalsuan yang sengaja dilakukan dengan tujuan memperdayakan orang lain. ${ }^{24}$

Betapapun masalah berbohong sayogyanya dipandang sebagai sesuatu yang tak lebih dari pada bagian perkembangan pikiran dan akal anak anda. Ketika anda mencoba menolong anak itu untuk melewati tahap perkembangan penting ini, camkanlah hal-hal seperti berikut:

\footnotetext{
${ }^{7}$ Ma'ruf Zurayk. Aku dan Anakku (Cet. I ; Bandung. Al-Bayan, 1994), 13-15.

${ }^{8}$ Singgih D. Ginarsa. Psikologi Anak Bermasalah. (Cet. II. Jakarta : Gunung Mulia, 1995), 2-6. 1986), 82 .

${ }^{24}$ Henry N. Siahan, Peranan Ibu Bapak Mendidik Anak (Cet. 10 ; Bandung : Angkasa,
} 
1) jangan menciptakan suasana atau keadaan yang biasa mendorong anak untuk berbohong.

2) Anggaplah bahwa kejadian-kejadian berbohong yang lalu, tidak pernah terjadi.

3) Hendaklah orang tua memberi contoh jangan sampai ia berbohong, terlebih dimuka anak-anak.

4) Biasakan mendidik anak sejak kecil agar tetap jujur.

5) Para orang tua perlu bersikap hangat, penuh pengertian, dorongan dan suka memaafkan. ${ }^{25}$

b. Anak penakut

Takut menandakan adanya suatu bahaya yang mungkin terjadi dan dan memperingatkan kita supaya lebih waspada. Perasaan takut timbul karena peristiwa tidak enak yang pernah dialaminya dulu.

Menghilangkan rasa takut anak, anda bisa melakukannya secara bertahap. Tekniknya adalah dengan membujuk dan mendekatkan anak pada obyek takutnya secara perlahan-lahan. ${ }^{26}$

c. Anak pemalu.

Sikap pemalu merupakan hasil keseimbangan antara keinginan atau hasrat dengan pengendalian diri yang mempunyai nilai positif dan mengandung perhitungan. Cara terbaik untuk mengatasi sifat pemalu dan agar anak berani berbicara dihadapan teman-tenannya, perlu diadakan latihan-latihan tertentu. ${ }^{27}$

Demikian besarnya pengaruh lingkungan keluarga (orang tua) terhadap perkembangan dan pembentukan kepribadian seorang anak. Karena keluarga adalah lingkungan yang pertama, pusat ketenangan hidup, sebagai pusat pendidikan.

\footnotetext{
${ }^{25}$ Alex Sabur, Anak Masa Depan (Cet. 10 Bandung : Angkasa, 2010), 123.

${ }^{26}$ Ibid, 133

${ }^{27}$ Siahaan, Peranan, 101
} 


\section{Perkembangan Kepribadian Anak}

\section{Pengertian Perkembangan dan kepribadian anak}

Perkembangan adalah perubahan yang terus menerus dialami, tetapi ia tetap menjadi kesatuan. perkembangan berlangsung dengan perlahan-lahan melalui masa demi masa. ${ }^{28}$

Untuk memasuki pembahasan tentang pengembangan kepribadian maka perlu kita ketahui hampir sama dengan istilah kepribadian yaitu karakter dan temperamen, ketika istilah tersebut mempunyai persamaan disatu pihak tetapi dipihak lain terdapat perbedaan.

Ahmad D Marimba memberi batasan sebagai berikut : karakter lebih menjurus kearah tabiat"yang dapat disebut benar atau salah, sesuai atau tidak sesuai dengan norma-norma sosial yang diakui. Temperamen ialah satu segi dari kepribadian yang erat hubungannya dengan keseimbangan zat-zat cair yang ada dalam tubuh. Kepribadian adalah lebih luas artinya, meliputi kualitet keseluruhan dari seseorang. kualitet akan tampak dalam cara-caranya berbuat, berfikir, caracaranya mengeluarkan pendapat, sikapnya minatnya filsafat hidupnya serta kepercayaannya. $^{29}$

Oleh karena itu untuk memperoleh gambaran tentang kepribadian maka terlebih dahulu harus diketahui apakah itu kepribadian. Kepribadian menurut Sadli, dalam bukunya kepribadian dan perubahan, mengatakan bahwa :

Teori tentang kepribadian makin luas tetapi makin kurang jelas. banyak istilah lain yagn dipakai namun sebetulnya orang ingin bicara tentang kepribadian, seperti diri manusia, watak, karakter, ego, oknum, pribadi, jiwa, pengetahuan diri, kadang-kadang orang memakai bahsa inggris bicara tentang self, personaliti, character, acharning, person. ${ }^{30}$

Memperhatikan uraian diatas, maka untuk lebih jelasnya penulis memberikan pengertian kepribadian dari segi etimologi, dan segi terminology. Pengertian kepribadian dari segi etimologi. menurut Agus Sujanto, et-al yaitu : 2001), 27.

${ }^{28}$ Zulkifli T, Psikologi Perkembangan (Cet.8.Bandung : PT. Remaja Rosda Karya,

${ }^{29}$ Ahmad. D. Marumba Pengantar Filsafat Pendidikan Islam (cet. viu : Bandung : PT. Al ma;rif, 1989), 66.

${ }^{30}$ Safarina Sadli. et. al. Kepribadian dan Perubahannya (Jakarta : PT. Gramedia, 1979), 3 
Kata kepribadian di etimologikan dari kata personality (bahasa inggris) yang berasal dari kata personal (bahasa latin) yang berarti kedok atau topeng, yaitu tutup muka yang sering dipakai oleh pemain-pemain panggung yagn maksudnya adalah untuk menggambarkan prilaku, watak atau pribadi seseorang. sedangkan dari segi terminology, penulis mengemukakan beberapa pendapat dari para ahli, diantaranya :

a. Menurut Sujanto :

Kepribadian adalah suatu totalitas psikophisis yang kompleks dari individu sehingga nampak dalam tingkah lakunya yang unik. ${ }^{31}$

b. Menurut All port.

Kepribadian adalah cara bertindak yang khas dari seseorang yang menghadapi peransang" sosial dan mutu dari penyelesaian diri yang dilakukannya terhadap aspek sosial dalam masyarakat. ${ }^{32}$

\section{Perkembangan kepribadian}

\section{Masa-masa perkembangan anak}

Menurut Para Ahli Jiwa

1. Pembagian Aristoteles, Ada tiga masa perkembangan, yaitu :

a. Priode anak kecil (kleuter), usia sampai 7 tahun.

b. Priode anak sekolah, usia 7 sampai 14 tahun.

c. Priode pubertas (remaja), usia 14 sampai 21 tahun.

2. Pembagian Comenius

a. Masa sekolah ibu, sampai usia 6 tahun

b. Masa sekolah bahasa ibu, usia 6 sampai 12 tahun

c. Masa sekolah bahsa latin, usia 12 sampai 18 tahun

d. Masa sekolah tinggi, usia 18 sampai 24 tahun

3. Pembagian ch. Buhler

a. Masa pertama, usiasampai 1 tahun.

Pada masa ini anak berlatih mengenal dunia lingkungan dengan berbagai macam gerakan.

b. Masa kedua, usia 2 sampai 4 tahun.

keadaan dunia luar makin dikuasai dan dikenalnya melalui bermain, kemajuan bahasa, dan pertumbuhan kemauannya.

c. Masa ketiga, usia 5 sampai 8 tahun.

keinginan bermain berkembang menjadi semangat bekerja.

${ }^{31}$ Marimba, Pengantar, 10.

${ }^{32}$ Ibid, 9. 
d. Masa keempat, usia 9 sampai 13 tahun.

Keinginan maju dan memahami kenyataan mencapai puncaknya.

e. Masa kelima, usia 14 sampai 19 tahun.

pada awal masa pubertas anak kelihatan lebih subjektif.

4. Pembagian Kohastamin

a. Masa vital (penyusu), sampai usia satu setengah tahun.

b. Masa anak kecil (estetis), usia satu setengah sampai 7 tahun

c. Masa anak sekolah (intelektual), usia 7 sampai dengan 14 tahun.

d. Masa remaja, usia 14 sampai dengan 21 tahun.

e. Masa dewasa (matang), usia 21 keatas.

\section{Pembagian Oswal Kroh}

Oswal kroh mendasarkan pembagian masa perkembangan masa perkembangan. Pada krisis-krisis yang dialami dalam proses perkembangan. Oswal tidak menggunakan istilah pubertas, ia Menggunakan istilah pubertas, ia menggunakan trot-trot priode seperti pembagian dibawah ini :

a. Tro-trot priode pertama

Anak mengalami masa krisis pertama ketika ia berusia 3 tahun

b. Trot-trot priode kedua

Anak mengalami masa krisis kedua ketika ia berusaha 12 sampai 14 tahun. oswal menyebutkan masa keserasian.

c. Trot-trot priode ketiga lebih tepat disebut masa kematangan dari pada masa krisis.

6. Pembagian Jean Piaget

a Fase sensorik motorik

b Fase pra operasional

c Fase operasi konkret

d Fase operasi konkrit

e Fase operasi formal. ${ }^{33}$

\section{Belajar sebagai bentuk perkembangan}

Menurut Murphy, proses belajar terjadi karena adanya interaksi antara organisme yang dasarnya bersifat individual dan lingkungan khusus tertentu. sebagai dari pada interaksi ini, maka terbentuklah koneksi antara kebutuhan" yang mengubah tegangan . koneksi" antara kondisi-kondisi jaringan dalam dan bentuk-

${ }^{33}$ Zulkifli L, Psikologi, 18-21. 
bentuk tingkah laku itu terbentuk oleh dua macam proses, yaitu kanalisasi dan persyaratan .

Kekuatan sesuatu kanalisasi itu menurut Murphy dapat diperhitungkan dan ini tergantung pada empat faktor.

a. Kekuatan kebutuhan, yaitu konsentrasi dalam jaringan

b. Intensitas kepuasan, yaitu besarnya perubahan tegangan.

c. Taraf atau fase perkembangan tertentu

d. Frekuensi kepuasan. ${ }^{34}$

Perkembangan fungsi-fungsi jiwa pada masa sekolah.
a. Pengamatan
b. Sikap jiwa dan perhatian
c. Pikir
d. Ingatan
e. Khayalan
f. Perasaan
g. Kemauan

Faktor-faktor yang mempengaruhi perkembangan anak.

d. Faktor dalam.

Faktor dalam adalah segala potensi, bakat dan kemampuan/ pembawaan yagn dimiliki anak sejak anak itu lahir. faktor ini makin lama makin berkembang dan makin banyak diferensiasi.

e. Faktor luar

Faktor ini sering disebut faktor ekstern atau faktor lingkungan. yang termasuk faktor ini antara lain: suasan, pergaulan, pendidikan, pengaruh, perangsang, keadaan iklim, sosial ekonomi, kebudayaan dan kegiatan sosial.

f. Kegiatan anak sendiri

Faktor lain yang menentukan juga perkembangan anak, yakni kegiatan anak sendiri. misalnya anak mempunyai pembawaan untuk bercakapcakap. pengaruh dan perangsang ada tetapi kalau anak sendiri tidak ada keaktifan mengembangkan kemampuan berbahasa dengan sempurna. ${ }^{35}$

\section{Hukum dan teori perkembangan.}

Hukum-hukum perkembangan:

a. Hukum konvergensi (perpaduan).

\footnotetext{
${ }^{34}$ Ibid, 35-36.

${ }^{35}$ Ibid.,
} 
b. Hukum mempertahankan diri dan perkembangan .

c. Hukum kesatuan organis

d. Hukum tempo perkembangan

e. Hukum irama perkembangan.

f. Hukum masa peka

g. Hukum perbandingan dimasa perkembangan

h. Hukum predestinasi

i. Hukum rekapitulasi

\section{Teori-teori perkembangan}

a. Teori nationalisme

Teori ini mempunya pandangan bahwa manusia sejak lahir telah memiliki sejumlah potensi yang akan dapat membantu kepribadiannya. faktor pembawaan inilah yang menentukan apakah dia bersifat manusia atau binatang, tinggi dan rendah drajatnya. sehingga interaksinya dengan lingkungan tidak akan mampu mempengaruhu kepribadiannya, termasuk pendidikan. hasil interaksi dengan lingkungan hanya mampu menjadi wadah rangsangannya saja yaitu hanya mampu membungkus kulit tidak mampu merubah. ${ }^{36}$

\section{b. Teori Imprisme}

Teori ini berpendapat bahwa anak dilahirkan bagaikan kertas putih yang kosong yaitu tidak membawa apa-apa. di akan terbentuk berdasarkan volume interksinya dengan lingkungan seseorang dapat mempunyai sifat kemanusiaan ketika didikan menjadi manusia. ${ }^{37}$

\section{c. Teori Konvergensi}

Berpendapat bahwa pembentukan kepribadian murid atau seseorang itu ditentukan dan diakibatkan sebagai sebagai proses interaksi antara faktor intern dan faktor ekstern. hal ini dapat kita analogikan seperti jagung. Jagung memiliki sejumlah potensi untuk tumbuh subur dan baik. Hal tersebut dapat kita lihat ketika jagung yang memiliki potensi itu kita tanam ditanah yang subur dan dirawat dengan baik dengan pemupukan yang sempurna, dan potensi tersebut akan hilang ketika ditanam ditempat atau tanah yang tandus kering. seperti itu siswa ketika

${ }^{36}$ M. Ngalim purwanto, Psikologi Pendidikan (Bandung : PT. Remaja Ros dakarya, 2001), 14.

${ }^{37}$ Ibid, 15 . 
mereka ditempatkan ditempat yang baik, Insya Allah akan menjadi baik dan ketika ditempatkan pada tempat yang buruk juga akan menjadi buruk. ${ }^{38}$

\section{Pertumbuhan Akal Pada Anak}

Menurut plato, akal adalah benda rohani yang tidak dapat ditangkap oleh pancaindra.

a. Usaha-usaha untuk mewujudkan pertumbuhan akal

- Dengan memberikan pengertian “dan kenyataan” baru kepada murid, karena dengan bertambahnya pengetahuan murid akalnya jadi tumbuh dengan baik.

- Dengan memberikan latihan "yang baik dan berfaedah kepada murid, karena adanya latihan". itulah akal itu dapat diasah, dan dapat nberpikir dengan baik.

b. Faktor-faktor yang mempengaruhi pertumbuhan akal.

- Faktor warisan (keturunan)

1. Warisan dekat, yaitu warisan dari dua orang Ibi, Bapak dan nenek moyang

2. Warisan jauh, yaitub warisan dari jenis manusia

- Faktor lingkungan

1. Lingkungan keluarga

2. Lingkungan sekolah.

\section{Perkembangan Tingkah Laku Sosial Anak}

Kita semua ketahui bahwa kita sebagai manusia tidak bisa hidup terpisahpisah didunia ini semenjak kita lahir telah masuk kedalam kelompok manusia, kita lahir kedunia sebagai anak dari ibu bapak kita. jadi tiap manusia senantiasa ada hubungannya dengan manusia yang lain. untuk itu kita sering sebutkan dengan sebutan pergaulan hidup, perkataan ini menunjukkan bahwa kita sebagai individu hidup bersama-sama.

Dalam hubungan anak sejak lahir sampai kemasa dewasanya dapat kita bagi atas beberapa bagian masa yakni:

${ }^{38} \mathrm{Ibid}, 15$. 
a. Masa bayi

Bayi itu hanya diberi makan (disusui) saya, tidur bermain-main dengan jari tangan dan kaki.

b. Masa kanak-kanak sampai 6 tahun.

Anak itu telah sadar bahwa ia sebagian dari keluarganya yaitu masyarakat kecil tempat ia hidup. disini juga dipelajari mana yang baik dan mana yang buruk

c. Masa anak-anak yang masuk sekolah (6-7 tahun).

Anak itu masuk dalam lingkungan baru yang berbeda sekali tata tertib dan peraturannya. pada anak timbullah semacam kesangsian, semacam pertengahan dalam hidup anak.

d. Masa anak sekolah yang harmonis (antara umur 8 tahun)

Anak itu telah menyesuaikan diri kepada situasi baru di sekolah,

e. Masa sesudah anak berumur 10-12 tahun.

timbullah perubahan lain, kecaman/ kritik kepada oaring tua dan gurunya banyak dikeluarkan dalam hidupnya. hal yang selama ini didengar dan dipercayainya, mulai disangsikan kesangsiang dan kecaman itu tumbuh terus dan berkembang seluas-luasnya. ${ }^{39}$

Murphy mengakui pula bahwa faktor sosial kulturil mempengaruhi kepribadian dalam empat acra yaitu :

a. Masyarakat mempunyai suatu rangkaian tanda-tanda yang menjadi tujuan persyaratan anak-anak yang hidup didalamnya.

b. Masyarakat melalui berbagai lembaga membawa anak-anak untuk manganalisasikan energi mereka

c. Masyarakat, dengan hadiah dan hukuman dapat mengubah dorongan “ implilulsif menjadi dorongan yang ditekan tidak hilang, pada suatu kali akan muncul lagi

d. Masyarakat, didalam proses"perseptif dan kognitif dapat membawa anggota-anggotanya sedemikian rupa, sehingga mereka akan belajar dalam berfikir sesuai dengan norma-norma masyarakat. ${ }^{40}$

\footnotetext{
${ }^{39}$ Daryanto. Bagaimana Jiwa Anak Anda.(Cet.I.Bandung : CV. Armoco. 1983), 17
}

${ }^{40}$ Sujana, dkk, Psikologi, 136-137. 
318 | MUSA WA, Vol. 13 No.2 Desember 2021 : 293-319

\section{KESIMPULAN}

Lingkungan keluarga merupakan lingkungan yang pertama dikenal oleh anak. Anak menghabiskan waktu dengan keluarga. Di lingkungan keluarga, orangtua mempunyai peran penting dalam pembentukan kepribadian anak, karena segala hal yang menjadi kebiasaan orangtua dapat ditiru oleh anak. Orangtua merupakan figur bagi anak, karena orangtualah yang mengasu dan mendidik anak sejak kecil. Kepribadian anak tergantung bagaimana orangtua mendidik dan membiasakan anak tersebut. Jika peran orangtua dalam mendidik anak benar, maka anak dapat tumbuh menjadi anak yang mempunyai kepribadian dan karakter yang baik. Menjadi orangtua harus benar-benar memperhatikan tumbuh kembang anak serta memperhatikan proses perkembangan anak, terutama memberi teladan yang baik.

\section{DAFTAR PUSTAKA}

Arikunto Suharsini, Prosedur Penelitian, Suatu Pendidikan Praktek, edisi. Revisi IV, cet. 11; Jakarta : PT. Rineka Cipta

Departemen Agama RI. Alqur'an dan Terjemahnya. Bandung, Mizan, 2009.

Daryanto. Bagaimana Jiwa Anak anda . Cet. I ; Bandung. CV. Armico 1983 http://repository.uinsu.ac.id/842/2/ISI\%20PSIKOLOGI\%20PEND.pdf, Diakses 27 November 2021.

Gunarsa, D. singgih. Psikologi Perkembangan. Cet. II; Jakarta : PT. Bpk. Gunung Mulia, 1995

https://www.academia.edu > MAKALAH_KEPRIBADian, Diakses 27 November 2021.

Katsir, Ibnu. Tafsir Ibnu Katsir (Jilid 7) Cetakan Ke. II. Jakarta: Pustaka Imam As-Syafi'I, 2010.

Marimba, D. Ahmad. Penantar Filsafat Pendidikan Islam, Cet, VII ; Bandung. PT. Al-Ma'rif 1989

Prabu Anwar. Perkembangan Intelegensi Anak dan Pengukuran IQ-nya Cet. 10, Bandung : Angkasa 1993 
Irawan, Peranan Lingkungan ... | 319

Purwanto. M. Ngalim. Psikologi Pendidikan. Bandung, PT. Remaja Rosdakrya

Sadli, Safarina. Kepribadian dan Perubahannya. Jakarta. PT. Gramedia 1979

Sari, Widya, Rifki, Andi Muhammad dan Mila Karmila, Analisis Kebijakan Pendidikan Terkait Implementasi Pembelajaran Jarak Jauh Pada Masadarurat Covid19, Karmila, https://jurnal.iain-bone. Ac id/in dex.p hp/mappe sona/articl e/download /830/562.

Siahan N Henry. Peranan Ibu Bapak Mendidik Anak. Cet, X ; Bandung. Angkasa. 1986

Sobur, Alex. Anak Masa Depan, Cet, 10 ; Bandung. Angkasa. 1991

Sujana. Agus dkk. Psikologi Kepribadian. Cet. IX; Jakarta. Bumi Aksara. 2001

Widaryanti, Sri. dkk. Reformasi Pendidikan Dasar. Cet, I ; Jakarta. PT. Grasindo. 2002

Zulkifli. Psikolologi Perkembangan. Cet, VIII ; Bandung PT. Remaja Rosdakarya. 2001

Zurayk. Ma'ruf. Aku dan Anakku. Cet, I ; Bandung. Al-Bayan. 1994 